\title{
Evaluation of risk factors and development of acute kidney injury in aneurysmal subarachnoid hemorrhage, head injury, and severe sepsis/septic shock patients during ICU treatment
}

\author{
Ceren Kamar, M.D., ${ }^{1}$ Achmet Ali, M.D., ${ }^{1}$ Demet Altun, M.D., ${ }^{1}$ Günseli Orhun, M.D., ${ }^{1}$ \\ Akın Sabancı, M.D., ${ }^{2}$ Altay Sencer, M.D., ${ }^{1}$ İbrahim Özkan Akıncı, M.D. ${ }^{1}$
}

${ }^{1}$ Department of Anesthesiology, İstanbul University İstanbul Faculty of Medicine, İstanbul-Turkey

2Department of Neurosurgery, İstanbul University İstanbul Faculty of Medicine, İstanbul-Turkey

\begin{abstract}
BACKGROUND: There are few studies examining development of acute kidney injury (AKI) in the various types of patients in intensive care units (ICUs). Presently described is evaluation of risk factors and development of AKI in different groups of ICU patients.

METHODS: Present study was performed in 3 different ICUs. Development of AKI was measured using Acute Kidney Injury Network (AKIN) classification system. Total of 300 patients who were treated in trauma, neurosurgery, or general ICU departments (due to head injury, aneurysmal subarachnoid hemorrhage [aSAH], or severe sepsis/septic shock, respectively) were assessed for incidence, risk factors, and development of AKI.
\end{abstract}

RESULTS: AKI did not develop in aSAH patients when evaluated based on serum creatinine level; however, it was observed in $5 \%$ of aSAH patients according to volume adjusted creatinine (VACr) level. AKI developed in $76 \%$ of sepsis group, and in $20 \%$ of head injury group, based on AKIN classification, according to both serum and VACr levels. Incidence of AKI was significantly higher in sepsis group $(\mathrm{p}<0.00 \mathrm{I})$. Only use of vasopressor was significantly related to AKI development in sepsis and head injury groups. Mortality rate was $8 \%, 22 \%$, and $42 \%$ in aSAH, head injury, and sepsis groups, respectively. AKI development and vasopressor use were significantly related to mortality in sepsis group.

CONCLUSION: Despite similar characteristics and risk factors, there were fewer instances of AKI in aSAH group. Hypertension or hydration therapy used to treat vasospasm and polyuria due to cerebral salt-wasting syndrome may prevent aSAH patients from developing AKI.

Keywords: Head trauma; renal insufficiency; sepsis; subarachnoid hemorrhage.

\section{INTRODUCTION}

Acute kidney injury $(\mathrm{AKI})$ is common in intensive care units (ICUs) and adversely affects patient morbidity and mortality. ${ }^{[1]}$ Despite this fact, there is no consensus on definition of $\mathrm{AKI}$; the condition includes broad clinical spectrum from

Address for correspondence: İbrahim Özkan Akıncı, M.D.
İstanbul Üniversitesi İstanbul Tıp Fakültesi, Anesteziyoloji
Anabilim Dalı, İstanbul, Turkey
$\begin{array}{ll}\text { Tel: }+90212-414 \text { I2 } 00 \text { / } 32553 \quad \text { E-mail: iozkana@gmail.com } \\ \text { Qucik Response Code } & \text { Ulus Travma Acil Cerrahi Derg } \\ & \text { 20I7;23(I):39-45 } \\ & \text { doi: I0.5505/tjtes.20I6.8345। } \\ & \text { Copyright 20I7 }\end{array}$

modest changes in creatinine $(\mathrm{Cr})$ level to decreasing glomerular filtration rate, decreased urine output, and eventually, anuria. Currently, 2 common tools defining AKI are the most routinely used assessment systems: risk, damage, failure, loss, and end-stage (RIFLE) classification and the Acute Kidney Injury Network (AKIN) classification..$^{[1,2]}$

Incidence of $A K I$ in ICU patients is approximately $67 \%$ and this condition directly affects their mortality. ${ }^{[3]}$ Risk factors for AKI are sepsis, high disease severity scores (Acute Physiology and Chronic Health Evaluation [APACHE] II and Sequential Organ Failure Assessment [SOFA]), vasopressor use, pulmonary disease, and malignancy. Despite large multicenter studies performed on the general population in ICUs, only limited number of studies have evaluated specific clinical situations. ${ }^{[1,4,5]}$ 
Sepsis is one of the most common medical problems in ICUs and is the most important risk factor for developing AKI. Therefore, many studies have assessed development of AKI. Incidence of various degrees of renal injury in these studies was as follows: $19 \%$ in patients with mild sepsis, $23 \%$ in severe sepsis patients, and $51 \%$ in patients with septic shock (serious enough to require dialysis for $15 \%$ to $20 \%$ of the patients with sepsis). ${ }^{[6,7]}$ Development of AKI and risk factors for AKI can vary in different clinical situations, such as head injury or subarachnoid hemorrhage, due to differences in treatment approach. Limited data are available regarding development of $A K I$ in ICU patients with aneurysmal subarachnoid hemorrhage (aSAH). Search revealed only I study on this subject, which identified development of $A K I$ in $0.8 \%$ to $7 \%$ of aSAH patients. However, evaluation criteria for diagnosing AKI were different at each center in this multicenter study. ${ }^{[8]}$ There are also few studies on non-neurological complications after traumatic brain injury; incidence of $A K I$ was reported to be $23 \%$. ${ }^{\text {[] }}$

Although many studies have examined development of $\mathrm{AKI}$ in all ICU patients, very few investigations have targeted specific ICU patient groups, such as those with subarachnoid hemorrhage, head injury, severe sepsis, and septic shock. Therefore, present study was conducted to compare 3 different patient groups (head injury, aSAH, and severe sepsis/septic shock) at 3 different ICUs for risk factors and development of AKI.

\section{MATERIALS AND METHODS}

This study was performed in neurosurgery ICU, emergency surgery and traumatology ICU, and adult general ICU after approval was obtained from the Istanbul Medical Faculty ethics committee. Patients were enrolled in the study after providing written, informed consent. This study began on January I, 2010. First 100 patients who had the following diagnoses from each ICU were evaluated: aSAH in neurosurgery ICU, head injury in emergency surgery and traumatology ICU, and sepsis in adult general ICU. Selection criteria for patients were as follows: ICU stay of more than $\mathbf{4 8}$ hours, age over 18 years, absence of chronic renal failure, and lack of pre-existing renal transplantation. Severe sepsis and septic shock were diagnosed based on the American College of Chest Physicians/ Society of Critical Care Medicine consensus criteria. ${ }^{[10]} \mathrm{Pa}-$ tients were monitored daily for development of renal failure based on AKIN classification criteria. ${ }^{[2]}$ Follow-up period was limited to 30 days.

Groups were as follows: aSAH patients in neurosurgery ICU (aSAH group), severe sepsis and septic shock patients in adult general ICU (sepsis group), and head injury patients in emergency surgery and traumatology ICU (head injury group). Age, gender, and additional diseases that could contribute to development of acute or chronic renal failure were recorded for each patient enrolled in the study. All patients were also evaluated on admission to ICU with APACHE II score using worst values of first day to evaluate disease severity. Common parameters of presence of infection, requirement for mechanical ventilation support, use of antibiotic therapy, use of vasopressor support, use of steroids or insulin, or presence of hyponatremia or hypernatremia were recorded. Degree of renal failure was determined based on AKIN classification. ${ }^{[2]}$ Patients were evaluated every day, and total urine output (in 24 hours) and/or daily $\mathrm{Cr}$ value was recorded. Data of each patient, including use of renal replacement therapy, length of ICU stay, and survival information, were recorded at end of ICU stay. Volume adjusted creatinine (VACr) level for all patient groups was calculated using the following formula described by Lui et al:: $\mathrm{VACr}=\mathrm{SCr} \times(\mathrm{I}+$ cumulative net fluid balance / total body water), in which $\mathrm{SCr}$ is measured serum creatinine and total body water is $0.6 \times$ patient weight on ICU admission. SCr, VACr level, and urine output were used to determine $A K I$ level in all patients. ${ }^{\left[{ }^{I I}\right]}$

Hydration and hypertension $(2 \mathrm{H})$ therapy were used to treat vasospasm in aSAH group, in contrast to other groups. Criteria for initiating $2 \mathrm{H}$ therapy included at least 2 minor signs of vasospasm (e.g., headache, agitation, rising white blood cell count without infection, development of new motor loss, decrease of more than 2 points on Glasgow Coma Scale [GCS]). For $2 \mathrm{H}$ therapy, at least $3500 \mathrm{~mL} /$ day intravenous fluid was used for hydration, and norepinephrine was used to induce hypertension (systolic blood pressure >160 mmHg). Clinical vasospasm was diagnosed with existence of 3 symptoms, such as headache, development of new neurological deficit, or decrease of more than 2 points on GCS.

All the data were evaluated using SPSS 16.0 statistical program for Windows (IBM Corp., Armonk, NY, USA). Data were expressed as mean value \pm standard deviation, and categorical variables were expressed as percentage of number of cases. $P$ value $<0.05$ was considered significant. Chi-square test, Mann-Whitney $U$ test and multivariate logistic regression analysis (to determine risk factors for AKI development and mortality) were used to determine clinically and statistically significant variables that were predeterminants of acute renal failure and mortality.

\section{RESULTS}

Total of 300 patients were evaluated in this study. Demographic data of the groups and morbidity and mortality rates are displayed in Table I. Sepsis group exhibited highest mortality; aSAH group mortality rate was lower than that of head injury group (Table I).

\section{Development of AKI}

VACr level was calculated for all groups, but result only differed from $\mathrm{SCr}$ level in aSAH group. Although there was no $\mathrm{AKI}$ in aSAH group according to $\mathrm{SCr}$ level, there were 5 (5\%) patients with AKI based on VACr level. AKI developed 
Table I. Demographic data and clinical characteristics of the 3 groups

\begin{tabular}{lcccc}
\hline & $\begin{array}{c}\text { aSAH group } \\
(\mathbf{n}=100)\end{array}$ & $\begin{array}{c}\text { Sepsis group } \\
(\mathbf{n}=100)\end{array}$ & $\begin{array}{c}\text { Head injury group } \\
(\mathbf{n}=100)\end{array}$ \\
\hline Female/Male & $64 / 36$ & $50 / 50$ & $28 / 72$ & $<$ \\
Age (years) & $51.0 \pm 11.3$ & $58.2 \pm 17.0$ & $35.7 \pm 14.8$ & 0.006 \\
Hypertension (\%) & 64 & 54 & 8 & $<$ \\
Diabetes mellitus (\%) & 26 & 36 & 4 & 0.004 \\
Ischemic heart disease (\%) & 18 & 28 & 24 & 0.001 \\
Mortality & 8 & 42 & $<0.001$ \\
\hline
\end{tabular}

aSAH: Aneurismal subarachnoid hemorrhage.

Table 2. Classification of acute kidney injury based on AKIN classification

\begin{tabular}{|c|c|c|c|c|c|c|c|c|}
\hline & \multicolumn{8}{|c|}{ Acute Kidney Injury Network } \\
\hline & \multicolumn{4}{|c|}{ aSAH group } & \multicolumn{2}{|c|}{ Sepsis group } & \multicolumn{2}{|c|}{ Head injury group } \\
\hline & $\mathbf{n}$ & $\%$ & $\mathbf{n}$ & $\%$ & $\mathbf{n}$ & $\%$ & & \\
\hline No. & 100 & 100 & 95 & $95^{*}$ & 24 & 24 & 80 & 80 \\
\hline Stage I & - & - & 5 & $5^{*}$ & 14 & 14 & 12 & 12 \\
\hline Stage 2 & - & - & - & - & 30 & 30 & 4 & 4 \\
\hline Stage 3 & - & - & - & - & 32 & 32 & 4 & 4 \\
\hline Total & - & - & 5 & $5^{*}$ & 76 & 76 & 20 & 20 \\
\hline
\end{tabular}

aSAH: Aneurismal subarachnoid hemorrhage. *: According to volume adjusted creatinine level.

in 76 patients $(76 \%)$ in sepsis group, and also developed in 20 patients $(20 \%)$ in head injury group, based on AKIN classification. AKI incidence in aSAH, head injury, and sepsis groups is provided in Table 2; difference between groups was statistically significant $(p<0.0 \mathrm{I}) . \mathrm{Cr}$ value at admission and discharge from ICU were compared between groups; $\mathrm{Cr}$ value was similar for all groups at admission $(p=0.68)$. However, upon last measurement before discharge, average $\mathrm{Cr}$ value was significantly higher in sepsis group than in the other 2 groups according to both SCr and VACr levels $(p<0.001)$. Furthermore, average $\mathrm{Cr}$ value on discharge was significantly higher in head injury group than in aSAH group $(p=0.006)$. Blood urea nitrogen (BUN) value at admission to ICU was statistically higher in sepsis group than in the other groups $(p<0.001)$. Mean BUN value was lowest in aSAH group at discharge from ICU, and it was highest in sepsis group ( $p<0.001$ ) (Table 3$)$. Cr value decreased from admission to discharge only in aSAH group; in this group, $64 \%$ of the patients received $2 \mathrm{H}$ therapy for vasospasm. Moreover, in aSAH group, $38 \%$ of patients developed sodium imbalance, $32 \%$ of the patients exhibited cerebral salt-wasting syndrome or syndrome of inappropriate antidiuretic hormone secretion-induced hyponatremia (<130 mEq/L), and $6 \%$ of the patients had hypernatremia with diabetes insipidus (>155 mEq/L).
Evaluation of risk factors associated with development of AKI IIIness Severity Score: Sepsis group average APACHE II score was significantly higher than that of the other 2 groups $(p<0.00 I)$, and head injury group average APACHE II score was higher than that of aSAH group $(p<0.00 \mathrm{I})$ (Table 4).

Age: Age of sepsis and aSAH groups was significantly higher than age of head injury group $(p<0.0001)$, but there was no significant difference between age of sepsis and aSAH groups $(p=0.4 I)$ (Table I).

ICU length of stay: Length of stay in ICU was significantly higher in sepsis group than in head injury group $(p<0.00 \mathrm{I})$; there was no significant difference between sepsis and aSAH groups (Table 4).

Vasopressor use: Use of vasopressor was significantly higher in sepsis group than other groups $(p<0.001)$, and it was similar between head injury and aSAH groups $(p=0.503)$ (Table 4).

ICU infections: As expected, number of infections in sepsis group was significantly higher than in head injury and aSAH groups $(p<0.001)$; there was no significant difference in in- 
Table 3. Creatinine and blood urea nitrogen levels of the groups at admission and discharge

\begin{tabular}{lcccc}
\hline & aSAH group & Sepsis group & Head injury group & p \\
\hline Creatinine $(\mathrm{mg} / \mathrm{dL})$ at admission & $0.98 \pm 0.23$ & $1.20 \pm 0.36$ & $0.96 \pm 0.25$ & 0.68 \\
BUN at admission & $14.64 \pm 3.61$ & $29.48 \pm 17.64$ & $17.38 \pm 9.69$ & $<0.001$ \\
Creatinine $(\mathrm{mg} / \mathrm{dL})$ at discharge & $0.47 \pm 0.16 / 0.52 \pm 0.17^{*}$ & $1.26 \pm 0.46$ & $0.69 \pm 0.35$ & $16.98 \pm 7.49$ \\
Blood urea nitrogen at discharge & $10.28 \pm 2.99$ & $30.64 \pm 10.05$ & 6001 \\
Renal support (\%) & 0 & 38 & 8 & $<0.001$ \\
Sodium imbalance (\%) & 38 & 0 & - \\
\hline
\end{tabular}

aSAH: Aneurismal subarachnoid hemorrhage, *: Volume adjusted creatinine level.

Table 4. Evaluation of factors that could be related to survival and renal failure in the groups

\begin{tabular}{|c|c|c|c|c|}
\hline & aSAH group & Sepsis group & Head injury group & $\mathbf{p}$ \\
\hline APACHE II (Mean $\pm S D)$ & $6.7 \pm 2.3$ & $19.1 \pm 5.5$ & $12.3 \pm 3.5$ & $<0.001$ \\
\hline ICU length of stay (days), (Mean \pm SD) & $14.2 \pm 6.8$ & $15.7 \pm 5.2$ & $10.5 \pm 5.9$ & $<0.001$ \\
\hline Vasopressor use, n (\%) & $9(18)$ & $31(62)$ & $18(36)$ & $<0.001$ \\
\hline Infection, n (\%) & $13(26)$ & $50(100)$ & $18(36)$ & $<0.001$ \\
\hline Duration of antibiotic use (day), (Mean \pm SD) & $2.8 \pm 5.2$ & $13.9 \pm 4.2$ & $3.6 \pm 5.3$ & $<0.001$ \\
\hline Insulin use (\%) & 38 & 58 & 34 & 0.035 \\
\hline Steroid use (\%) & 100 & 44 & 40 & $<0.001$ \\
\hline Mechanical ventilation (\%) & 60 & 80 & 86 & 0.004 \\
\hline
\end{tabular}

APACHE II: Acute physiology and chronic health evaluation score, ICU: Intensive care unit, aSAH: Aneurismal subarachnoid hemorrhage.

cidence of infection between head injury and aSAH groups $(p=0.387)$ (Table 4).

Antibiotic use: Average duration of antibiotic use was significantly higher in sepsis group than in other groups $(p<0.00 \mathrm{I})$, but was similar between aSAH and head injury group $(p=0.738)$ (Table 4).

Insulin use: There was greater use of insulin in sepsis group; however, there was no statistically significant difference between groups $(p=0.035)$ (Table 4$)$.

Steroid use: Steroids were used to treat all the patients in aSAH group, and usage was statistically significant compared with other 2 groups $(p<0.001)$. However, use of steroids was similar between sepsis and head injury groups $(p=0.875)$ (Table 4).

Mechanical ventilation: Requirement for mechanical ventilation in sepsis and head injury groups was similar $(p=0.454)$, and it was significantly higher in these groups compared with aSAH group $(p=0.004)$ (Table 4$)$.

\section{Evaluation of Mortality According To AKI}

Within sepsis group, mortality rate was significantly higher in
$A K I$ patients than in those patients who had no $A K I(p=0.018)$. However, there was no difference in mortality between $A K I$ and non-AKI patients in head injury group $(p=0.823)$. While aSAH group mortality rate was $8 \%$, there was no mortality in AKI group. Sepsis group mortality rate based on AKIN classification was $42.9 \%(n=6)$ in Stage I, $26.7 \%(n=8)$ in Stage 2, and $75 \%(n=24)$ in Stage 3. Mortality rate was higher in sepsis group than in other 2 groups. Mortality rate in head injury group was $24 \%$ based on AKIN classification system. Mortality rate was $33.3 \%(n=4)$ in Stage I, 50\% $(n=2)$ in Stage 2, and $50 \%(n=2)$ in Stage 3.

Multivariate logistic regression analysis was conducted to evaluate possible factors that could have affected mortality rate. No factor affecting patient mortality was found for aSAH group. In sepsis group, development of $A K I$ (odds ratio [OR]: I.89, 95\% confidence interval [Cl]: 0.86-2.92; $\mathrm{p}=0.022$ ) and vasopressor use (OR: I.2I, 95\% Cl: I.04-I.38; $\mathrm{p}=0.009$ ) were determined to have effect on mortality. In head trauma group, neither of these factors affected mortality. However, when all 300 patients were collectively evaluated, vasopressor use (OR: 2.2I, 95\% Cl: 0.45-4.0I; $\mathrm{p}=0.0 \mathrm{I}$ ) and requirement for mechanical ventilation (OR: I.53, 95\% Cl: 0.90-2. I5; $p=0.013$ ) increased mortality. 


\section{Detecting Risk Factors For Development of AKI}

Multivariate logistic analysis for risk factors that might cause AKI was performed for all groups. There was no significant risk factor for aSAH group. For sepsis group, vasopressor use was the only significant risk factor for developing AKI (OR: 0.04, 95\% Cl: 0.0I-0.06; $\mathrm{p}=0.038$ ), as was also the case for head injury group (OR: 4.89, 95\% Cl: 3.04-6.74; $\mathrm{p}=0.044$ ). When data from all groups were collectively analyzed, APACHE II scores (OR: I.2I, 95\% Cl: I.09-I.3I; $p<0.00 I$ ), steroid use (OR: 7.3I, 95\% Cl: 5.04-9.58; $p=0.003)$, and antibiotic use (OR: I.2I, 95\% Cl: I.00-I.40; $\mathrm{p}=0.043$ ) were determined to be significant risk factors for developing AKI.

\section{DISCUSSION}

Although AKI did not develop in any patient in aSAH group based on SCr level, by contrast, AKI was present in $5(5 \%)$ patients in the group according to VACr level during the 30day ICU follow-up period. Condition developed in 76 (76\%) patients in severe sepsis/septic shock group, and in 20 (20\%) patients in head injury group, based on AKIN classification. Vasopressor use was only significant risk factor for development of AKI in sepsis and head injury groups; however, high APACHE II score, as well as steroid and antibiotic use, were determined to be risk factors for AKI when all groups were analyzed collectively. We calculated VACr level according to fluid balance in aSAH group. Although there was no $A K I$ in aSAH group according to $\mathrm{SCr}$ level, after fluid adjustment and corrected calculation of $\mathrm{Cr}, 5$ patients received Stage I AKI diagnosis. Intense fluid management could influence $\mathrm{SCr}$ and Cr-based diagnosis of AKI. ${ }^{[1,12]} \mathrm{Cr}$ level could be low due to fluid overload as result of dilution. ${ }^{[2]}$ For this reason, we used VACr level in addition to SCr. But we did not observe any problem related to $\mathrm{AKI}$, such as longer hospital stay or inhospital mortality, in this group of patients.

Solenski et al. performed multicenter study of 457 aSAH patients in ICU in which they evaluated non-neurological problems, and they determined that AKI incidence in that group of patients was between $0.8 \%$ and $7 \% .{ }^{[8]}$ However, AKI was diagnosed only by rise in $\mathrm{Cr}$ and/or urea value. To our knowledge, the present study is the only one to utilize current AKI evaluation criteria for aSAH patients. Two main reasons may explain difference between our findings and Solenski's results on development of AKI. First, our patients exhibited normal renal function. Almost one-fifth of all ICU patients have different degrees of renal impairment, ${ }^{[5]}$ but this status was not indicated in Solenski's study; thus, mild renal impairment in those patients on admission to ICU might explain rate of AKI in that study. Second, there could have been a type II error in our study due to small number of patients. Another research group that evaluated effect of $\mathrm{AKI}$ on survival of aSAH patients (using RIFLE classification) determined that AKI patients exhibited 3-fold increase in mortality rate compared with non-AKI patients; this risk factor for poor prognosis confirmed patient statistics in our study. ${ }^{[5]}$ However, there are no data indicating that AKI either developed in ICU or was acquired on admission to this study. AKI patients with sepsis are older and have higher mortality rates and APACHE II scores compared with septic patients who do not develop AKI. ${ }^{[13]}$ Although our single-center study had limited number of patients, these findings confirmed our results. Several investigations have revealed that $\mathrm{AKI}$ develops in approximately I I \% to $42.1 \%$ of all sepsis cases depending on severity of the illness. ${ }^{[14,15]}$ In a German multicenter study, AKI developed in approximately $4 \mathrm{I} .4 \%$ of severe sepsis and septic shock cases. [16] In our study, AKI developed in $76 \%$ of patients in sepsis group. This rate is higher than that reported in other studies and might be explained by fact that $62 \%$ of the patients in sepsis group were in septic shock; however, this rate was not indicated in German study. Risk for development of AKI in sepsis group was increased by use of antibiotics and vasopressors. In another study, in which 415 severe sepsis and septic shock patients were examined for development of $\mathrm{AKI}$, mortality rate was $39.5 \%$ in non-AKI patients but was $64.6 \%$ in $A K I$ patients $(p<0.001)$. However, in this study, only development of AKI was determined to be significant risk factor for mortality. ${ }^{[17]}$ In our study, mortality rate for sepsis patients without $\mathrm{AKI}$ was $14.3 \%(2 / 14)$, but was $52.8 \%$ (19/36) for sepsis patients with AKI; this difference was significant $(p=0.013)$. Li et al. reported that $A K I$ developed in $23 \%$ of 136 traumatic brain injury patients (based on AKIN classification) and that average age of patient group who developed $\mathrm{AKI}$ was higher. They also found that mortality rate was greater in AKI group. ${ }^{[18]}$ In another study, based on RIFLE classification system, incidence of $\mathrm{AKI}$ was $9.2 \%$, and these patients were significantly older and had higher APACHE II scores compared with non-AKI patients. ${ }^{[19]}$ Furthermore, mortality rate was $42.1 \%$ in the patients who developed $\mathrm{AKI}$ and $18.1 \%$ in non-AKI patients. ${ }^{[19]}$ In our study, AKI developed in $20 \%$ of head injury patients, based on AKIN classification. Majority of the patients were male. Multivariate analysis revealed that vasopressor use $(p=0.044)$ was the only risk factor for developing AKI. We found no factor related to mortality. Mortality rate in this group was 19\% (8/42) for non-AKI patients and $37.5 \%$ for $\mathrm{AKI}$ patients, but difference was not statistically significant.

When all of the patients were assessed collectively, use of vasopressors (OR: 2.2I, 95\% $\mathrm{Cl}: 0.45-4.0 \mathrm{I} ; \mathrm{p}=0.0 \mathrm{I} 2$ ) and need for mechanical ventilation (OR: I.53, 95\% Cl: 0.90-2. I5; $\mathrm{p}=0.013$ ) were determined to be risk factors for mortality. However, development of AKI alone had no effect on mortality, in contrast with sepsis group. We suppose that this significant difference is due to younger patient profile in head injury group, which had smaller comorbid disease ratio and lower mortality rate among AKI patients compared with sepsis group. Whereas similar age, ICU length of stay, comorbid diseases, and $\mathrm{Cr}$ and BUN values were observed on admis- 
sion in aSAH group compared with sepsis group, similar infection rate and similar use of antibiotics and vasopressors were observed in head injury group. Moreover, steroids were used by all of the patients in aSAH group. Although aSAH group had similar risk factors for developing AKI compared with the 2 other groups, Stage I AKI based on VACr value developed in only 5 patients. Most of the patients with even minor signs of vasospasm underwent $2 \mathrm{H}$ therapy in aSAH group; we believe that this therapy could protect renal function. In addition, we also believe that electrolyte imbalance that commonly occurs in this patient group (due to cerebral salt-wasting syndrome, inappropriate secretion of antidiuretic hormone or central diabetes insipidus) and causes polyuria could also protect against renal injury. Risk factors for development of $\mathrm{AKI}$ were higher age, higher disease-severity scores (APACHE II and SOFA), vasopressor therapy, sepsis, pre-existing renal insufficiency, malignancy, and pulmonary disease.I When all of the patients in our study were evaluated using multivariate regression analysis, APACHE II score (OR: I.2I, 95\% Cl: I.09-I.3I; $\mathrm{p}<0.00 \mathrm{I}$ ) and use of steroids (OR: 7.32, 95\% Cl: 5.04-9.58; $p=0.003$ ) or antibiotics (OR: I.2I, 95\% Cl: I.00-I.40; $\mathrm{p}=0.043$ ) were determined to be risk factors for development of $\mathrm{AKI}$.

In conclusion, AKI developed in only $5 \%$ of aSAH patients, but occurred in $70 \%$ of the patients in sepsis group, and $20 \%$ of the patients in head injury group. Conditions and risk factors were similar in all groups, but $2 \mathrm{H}$ therapy was applied to $64 \%$ of aSAH patients. In addition, centrally originating electrolyte imbalances that cause polyuria may explain low incidence of $\mathrm{AKI}$ among aSAH patients. Results of our investigation might not accurately reflect general population as it was single-center study that included limited number of patients who were also renally intact. Therefore, multicenter studies with larger and more homogeneous patient populations are necessary to obtain more representative results.

Conflict of interest: None declared.

\section{REFERENCES}

1. Hoste EA, Clermont G, Kersten A, Venkataraman R, Angus DC, De Bacquer D, et al. RIFLE criteria for acute kidney injury are associated with hospital mortality in critically ill patients: a cohort analysis. Crit Care 2006;10:R73. Crossre

2. Mehta RL, Kellum JA, Shah SV, Molitoris BA, Ronco C, Warnock DG, et al. Acute Kidney Injury Network: report of an initiative to improve outcomes in acute kidney injury. Crit Care 2007;11:R31. Crossre.

3. Goldberg R, Dennen P. Long-term outcomes of acute kidney injury. Adv Chronic Kidney Dis 2008;15:297-307. Crossre

4. Vincent JL, Sakr Y, Sprung CL, Ranieri VM, Reinhart K, Gerlach H, et al. Sepsis in European intensive care units: results of the SOAP study. Crit Care Med 2006;34:344-53. Crossre]

5. Zacharia BE, Ducruet AF, Hickman ZL, Grobelny BT, Fernandez L, Schmidt JM, et al. Renal dysfunction as an independent predictor of outcome after aneurysmal subarachnoid hemorrhage: a single-center cohort study. Stroke 2009;40:2375-81. Crossret

6. Ingram J. Acute renal failure in intensive care. Anesthesia and Intensive Care Medicine 2006;7:116-8. Crossret

7. Schrier RW, Wang W. Acute renal failure and sepsis. N Eng J Med 2004;35:159-69. Crossret

8. Solenski NJ, Haley EC Jr, Kassell NF, Kongable G, Germanson T, Truskowski L, et al. Medical complications of aneurysmal subarachnoid hemorrhage: a report of the multicenter, cooperative aneurysm study. Participants of the Multicenter Cooperative Aneurysm Study. Crit Care Med 1995;23:1007-17. Crossre

9. Li N, Zhao WG, Zhang WF. Acute kidney injury in patients with severe traumatic brain injury: implementation of the acute kidney injury network stage system. Neurocrit Care 2011;14:377-81. Crossre

10. Bone RC, Balk RA, Cerra FB, Dellinger RP, Fein AM, Knaus WA, et al. Definitions for sepsis and organ failure and guidelines for the use of innovative therapies in sepsis. The ACCP/SCCM Consensus Conference Committee. American College of Chest Physicians/Society of Critical Care Medicine. Chest 1992;101:1644-55. Crossret

11. Liu KD, Thompson BT, Ancukiewicz M, Steingrub JS, Douglas IS, Matthay MA, et al. Acute kidney injury in patients with acute lung injury: impact of fluid accumulation on classification of acute kidney injury and associated outcomes. Crit Care Med 2011;39:2665-71. Crossret

12. Macedo E, Bouchard J, Soroko SH, Chertow GM, Himmelfarb J, Ikizler TA, et al. Fluid accumulation, recognition and staging of acute kidney injury in critically-ill patients. Crit Care 2010;14:R82. Crossre

13. Levy MM, Macias WL, Vincent JL, Russell JA, Silva E, Trzaskoma B, et al. Early changes in organ function predict eventual survival in severe sepsis. Crit Care Med 2005;33:2194-201. Crossret

14. Angus DC, Linde-Zwirble WT, Lidicker J, Clermont G, Carcillo J, Pinsky MR. Epidemiology of severe sepsis in the United States: analysis of incidence, outcome, and associated costs of care. Crit Care Med 2001;29:1303-10. Crossre

15. Bagshaw SM, George C, Bellomo R; ANZICS Database Management Committee. Early acute kidney injury and sepsis: a multicentre evaluation. Crit Care 2008;12:R47. Crossee

16. Oppert M, Engel C, Brunkhorst FM, Bogatsch H, Reinhart K, Frei U, et al. Acute renal failure in patients with severe sepsis and septic shock--a significant independent risk factor for mortality: results from the German Prevalence Study. Nephrol Dial Transplant 2008;23:904-9. Crossre

17. Yegenaga I, Hoste E, Van Biesen W, Vanholder R, Benoit D, Kantarci G, et al. Clinical characteristics of patients developing ARF due to sepsis/ systemic inflammatory response syndrome: results of a prospective study. Am J Kidney Dis 2004;43:817-24. Crossre

18. Bagshaw SM, George C, Dinu I, Bellomo R. A multi-centre evaluation of the RIFLE criteria for early acute kidney injury in critically ill patients. Nephrol Dial Transplant 2008;23:1203-10. Crossrel

19. Moore EM, Bellomo R, Nichol A, Harley N, Macisaac C, Cooper DJ. The incidence of acute kidney injury in patients with traumatic brain injury. Ren Fail 2010;32:1060-5. Crossre. 
ORIJINAL ÇALIŞMA - ÖZET

\section{Anevrizmal subaraknoid kanama, kafa travması ve sepsis hastalarının yoğun bakım tedavileri sırasında akut böbrek hasarı gelişimi ve etkileyen risk faktörlerinin incelenmesi}

\section{Dr. Ceren Kamar, ${ }^{1}$ Dr. Achmet Ali, ${ }^{1}$ Dr. Demet Altun, ${ }^{1}$ Dr. Günseli Orhun, ${ }^{1}$ Dr. Akın Sabancı, ${ }^{2}$ Dr. Altay Sencer, ${ }^{1}$ Dr. İbrahim Özkan Akıncı ${ }^{1}$}

${ }^{1}$ İstanbul Üniversitesi İstanbul Tıp Fakültesi, Anesteziyoloji Anabilim Dalı, İstanbul

${ }^{2}$ İstanbul Üniversitesi İstanbul Tıp Fakültesi, Beyin Cerrahisi Anabilim Dalı, İstanbul

AMAÇ: Yoğun bakım ünitelerinde (YBÜ) takip edilen farkı hasta gruplarında akut böbrek hasarı ( $A B H)$ gelişimini inceleyen az çalışma bulunmaktadır. Çalışmamızda farklı yoğun bakım hasta gruplarında $A B H$ gelişmesini ve bunda etkili risk faktörlerini incelemeyi amaçladık.

GEREÇ VE YÖNTEM: Bu çalışma üç farklı YBÜ'de gerçekleştirildi ve AKI network (AKIN) sınıflandırmasına göre ABH oluşumu karşılaştırıldı. Travma, beyin cerrahi ve genel YBÜ'lerde yatan sırası ile kafa travması, anevrizmal subaraknoid kanama (aSAK) ve septik şok nedeniyle takip edilen 300 hasta $\mathrm{ABH}$ insidansı ve risk faktörleri açısından incelendi.

BULGULAR: Anevrizmal subaraknoid kanama grubunda serum kreatin değerine göre $\mathrm{ABH}$ gelişen hasta saptanmadı fakat volüm düzeltilmiş kreatinin değerine göre $(\mathrm{VACr})$ hastaların \%5'inde $\mathrm{ABH}$ geliştiği görüldü. AKI network sınıflandırması baz alındığında sepsis grubunda \%76, kafa travması grubunda hastaların \%20'sinde hem serum kreatin hemde $\mathrm{VACr}$ değerine göre $\mathrm{ABH}$ geliştiği görüldü ve sepsis grubunda $\mathrm{ABH}$ insidansı anlamlı oranda yüksek bulundu $(p<0.00 I)$. Sadece vazopresör kullanımı sepsis ve kafa travması grubunda $A B H$ gelişimi için risk faktörü olarak saptandı. Hastaların mortalite oranları aSAK, kafa travması ve sepsis grubu için sırası ile \%8, \%22 ve \%42 saptandı. Vazopressör kullanımı ve $A B H$ gelişmesi sepsis grubunda mortalite için risk faktörü olarak saptandı.

TARTIŞMA: Benzer özellikler ve risk faktörlerine rağmen aSAK hastalarında $A B H$ daha nadir görülmektedir. Vazospazm tedavisi için uygulanan hipertansiyon, hipervolemi ve tuz kaybettirici sendrom sonucu oluşan poliüri aSAK hastalarında ABH gelişimden koruyan faktörler olabilir. Anahtar sözcükler: Böbrek yetmezlig̈i; kafa travmasi; sepsis; subaraknoid kanama.

Ulus Travma Acil Cerrahi Derg 2017;23(I):39-45 doi: 10.5505/tjtes.2016.8345 I 